\title{
Use of molecular epidemiological techniques in a pilot study on workers exposed to chromium
}

Min Gao, Leonard S Levy, Stephen P Faux, T Ching Aw, Robin A Braithwaite, Stanley S Brown

\begin{abstract}
Objectives-Molecular epidemiological techniques, capable of detecting damage to DNA, were used to see if such damage occurred in the lymphocytes of a group of workers exposed to chromium. The two aims of this pilot study were to see if these new techniques might make useful biological monitoring tools for workers exposed to chromium and also, to help assess whether the current occupational exposure limit for chromium (VI) was sufficiently protective in this specific working situation.
\end{abstract}

Methods-Volunteer groups of 10 workers exposed to chromium and 10 nonexposed workers provided urine and blood samples towards the end of the working week. Chromium concentrations were measured in whole blood, plasma, lymphocytes, and urine. Lymphocytes were used to examine two forms of DNA damage in the two groups; these were the level of DNA strand breakage and, the production of 8-hydroxydeoxyguanosine. Results-Chromium concentration in whole blood, plasma, and urine of workers exposed to chromium was significantly raised $(P<0.01)$ compared with non-exposed controls, but in isolated lymphocytes, there was only a modest but significant $(P<0.05)$ increase in chromium in the group exposed to chromium. There was no difference in the levels of DNA strand breaks or 8-hydroxydeoxyguanosine between the groups. Air monitoring for chromium was not undertaken but current levels for the group exposed to chromium were reported to be around $0.01 \mathrm{mg} / \mathrm{m}^{3}$, which is $20 \%$ of the current United Kingdom occupational exposure limit.

Conclusions-We were unable to detect any damage in lymphocytic DNA due to exposure to chromium. This may have been due to the low chromium exposure $(<20 \%$ of the United Kingdom occupational exposure limit), the ability of plasma to detoxify chromium (VI) to chromium (III) before it reached the lymphocytes, or perhaps the insensitivity of the molecular techniques used. It is now important to test these and other such techniques on groups exposed to levels closer to the United Kingdom occupational exposure limit.

(Occup Environ Med 1994;51:663-668)

Keywords: cancer, chromium, molecular epidemiology
The inhalation of aerosols containing chromium is the major route of exposure to chromium compounds in those industries where an increased risk of lung cancer has been shown. ${ }^{2}$ The airborne chromium concentration should, therefore, directly reflect the risk of lung cancer and other effects associated with exposure to chromium. The control of airborne chromium concentration, through air monitoring, has been used extensively to reduce risk. ${ }^{1}$ Monitoring the airborne chromium concentration in the working environment is the simplest method of maintaining chromium containing compounds below an agreed concentration. In the United Kingdom, the current occupational exposure limits are $0.5 \mathrm{mg} / \mathrm{m}^{3}$ for chromium(II) and chromium(III) (as occupational exposure standards) and $0.05 \mathrm{mg} / \mathrm{m}^{3}$ for chromium(VI) (as a maximum exposure limit (MEL). ${ }^{3}$ Monitoring ambient chromium concentrations may not necessarily indicate the amount of chromium absorbed into the body. ${ }^{4}$ This is due in part to the various valency states of airborne chromium used in industry, the relative solubilities of different chromium compounds and the extent of protection afforded by respiratory protective equipment. ${ }^{1}$ It is generally agreed that chromium(VI) is the valency state responsible for lung cancer induced by chromium and that it differs from chromium(III) compounds in its absorption and ability to cross cell membranes. ${ }^{5-7}$ Biological monitoring, as a means of assessing uptake, has been used to complement air monitoring and since the late 1960s, urinary chromium and blood chromium, have been used for biological monitoring of exposure in some industries. ${ }^{8-11}$ Also, erythrocytes ${ }^{12}$ and lymphocytes ${ }^{13}$ have been investigated to assess exposure to chromium(VI). Thus, biological monitoring and monitoring of biological effects on workers exposed to different valency states of chromium are becoming increasingly important as many people feel they might give a better estimate of risk.

Recently, molecular epidemiological studies of exposed human populations that used various genotoxic markers have been used as a new approach to assess exposure to carcinogens, where population surveys have been conducted at the level of DNA alterations. ${ }^{14}$ These techniques may be able to identify a risk of cancer long before cancer develops. ${ }^{15}$ Lymphocytes, which are an easily accessible target cell population, have often been used in such studies. ${ }^{14-18}$ As lymphocytes are readily available nucleated cells, they may have the potential to be used to predict DNA damage in cells in putative target organs, such as the 
lung. As a new approach, the quantitative relation of such indicators to the risk of developing cancer has not been determined and as screening tools their specificity and sensitivity have yet to be determined. ${ }^{19}$ There is a general consensus that genotoxic effects are -concerned with early stages in the multistep process of carcinogenesis, particularly for genotoxic carcinogens such as chromium(VI). Our previous studies have shown that chromium(VI) is able to induce DNA strand breaks in human lymphocytes both in vitro and in rat lymphocytes in vitro and in vivo. ${ }^{20}$ Furthermore, investigation of the formation of the oxidised deoxynucleoside 8-hydroxydeoxyguanosine $(8-\mathrm{OHdG})$ in isolated DNA after treatment with chromium(VI) or chromium(V) compounds suggested that the mechanism of toxicity might involve the production of hydroxyl radicals, probably through Fenton chemistry. ${ }^{21}$ Therefore, it was logical to investigate the outcome of real occupational chromium exposure on such DNA alterations in exposed humans as it may provide scope for these new techniques to be used for monitoring of exposed workers for biological effects.

In this paper, we present the first report exploring some of these techniques to investigate any association between chromium uptake (biological monitoring) and DNA damage (monitoring of biological effect) associated with exposure to chromium.

\section{Materials and methods}

STUDY POPULATION

Twenty volunteer subjects (15 men and five women) from a plant that produces bichromate in England participated in the study. Ten subjects were employed in chromate production and other work areas that produced materials that contain chromium. Ten control subjects who worked in the same plant but were not occupationally exposed to materials that contain chromium formed a comparison group-for example clerical and other professional staff. A questionnaire on general health, smoking and alcohol consumption, and occupational history, was given to all participants by an interviewer. The questionnaire also elicited information on potentially important confounders that could induce DNA damage, such as a radiographic examination during the last month and recent medication. The question on medication was also intended to elicit information about recent illness, including viral infection that may have been a con-

Table 1 Description of study population

\begin{tabular}{lll}
\hline & Exposed & Control \\
\hline Subjects (n (m/f)) & $10(10 / 0)$ & $10(5 / 5)$ \\
Mean (SD) age (y) & $44(7)$ & $40(10)$ \\
& & \\
Smoking: & 6 & 2 \\
$\quad$ Current & 1 & 2 \\
$\quad$ Ex & 3 & 6 \\
$\quad$ Non & $23(37)$ & $10(15)$ \\
Alcohol consumption (U/week (SD)) & $13(9)$ \\
Mean (SD) duration of employment (y) & $15(7)$ & $13(9)$ \\
\hline
\end{tabular}

founder. Table 1 shows the characteristics of the study population. Age and alcohol consumption were comparable between the two groups, but sex and smoking were not (table 1).

\section{MATERIALS CONTAINING CHROMIUM TO} WHICH WORKERS WERE EXPOSED

The chromium production plant investigated in this study has a long history of production. Although the production process has stayed much the same there have been plant and process modifications over the years that will have altered exposure patterns. ${ }^{22}$ The plant produces a wide range of chromium products, such as sodium dichromate, chromic acid, potassium dichromate, and chrome tanning agents. The primary production of sodium dichromate is based on the roasting of crushed and ground chromite ore (containing insoluble trivalent chromium oxide) with sodium carbonate. This produces sodium chromate (soluble and hexavalent). Further processing, including crystallisation and acidification, produces sodium dichromate, the starting material for many other substances that contain sodium. Other products are made on site from the reaction of sodium dichromate with other materials. Thus, although many of the compounds are hexavalent there will also be several trivalent compounds in the working environment.

At the time of this pilot study, no hygiene measurements were carried out, however, we were provided with general background monitoring information on airborne chromium concentrations in the plant, obtained from both personal and area samplers, and these ranged from 0.001 to $0.055 \mathrm{mg} \mathrm{Cr}(\mathrm{VI}) / \mathrm{m}^{3}$, but most areas were well below $0.01 \mathrm{mg}$ $\mathrm{Cr}(\mathrm{VI}) / \mathrm{m}^{3}$. This concentration is around one fifth of the current United Kingdom MEL $\left.(0.05 \mathrm{mg} \mathrm{Cr}(\mathrm{VI})) / \mathrm{m}^{3}\right)$.

COLLECTION OF BLOOD AND URINE

Blood $(16 \mathrm{ml})$ and spot urine $(40 \mathrm{ml})$ specimens were collected during the morning at the end of the working week. Blood was withdrawn from a vein in the arm with an Abbocath-T20G Teflon catheter (Abbot Ireland, Sligo, Republic of Ireland) and equally distributed into two sets of $10 \mathrm{ml}$ Monoject lithium-heparin coated tubes (Sherwood Medical, Ballymoney, Northern Ireland). All specimens were coded and placed in a cooled ice box. The subjects also provided spot urine specimens in $20 \mathrm{ml}$ sterile plastic containers (Bibby Sterilin, Stone, Staffordshire) that were also kept in the ice box. The subjects were instructed to change out of their work clothes and wash their hands before supplying the spot urine specimen (to limit chromium contamination). All samples were coded and placed in a cooled ice box that was transported from the plant to the laboratory on the day of collection.

ISOLATION OF LYMPHOCYTES AND PLASMA Lymphocytes were isolated by a hypotonic lysis method immediately after the specimens reached the laboratory. Precooled hypotonic 
solution $\left(9 \mathrm{ml} \quad 0 \cdot 87 \% \mathrm{NH}_{4} \mathrm{Cl}-10 \mathrm{mM}\right.$ Tris$\mathrm{HCl}, \mathrm{pH} \mathrm{7.2)}$ was added to disposable tubes (Cel-Cult, Sterilin, Hounslow) that were kept on ice. Blood ( $3 \mathrm{ml})$ was then added to each tube, gently mixed and left on ice for $30 \mathrm{~min}$ to lyse the red blood cells. Tubes were then centrifuged $(1300 \mathrm{rpm})$ for $20 \mathrm{~min}$ at $4^{\circ} \mathrm{C}$ and the pellet produced was resuspended in the hypotonic solution $(3 \mathrm{ml})$. This suspension was spun again, as described above, for 10 min to wash the lymphocyte preparation and the supernatant aspirated. The lymphocytes were then counted with a Neubauer haemocytometer. The plasma was separated by centrifugation (at $2000 \mathrm{rpm}$ for $10 \mathrm{~min}$ ) and then placed into disposable plastic tubes.

\section{ANALYSES OF DNA STRAND BREAKAGE AND DNA ADDUCTS IN LYMPHOCYTES}

Breaks in DNA strands were measured with a fluorometric alkaline unwinding assay that was based on the method described by Birnboim and Jevcak ${ }^{23}$ with slight modifications. ${ }^{20}$ The method is highly sensitive (sufficient to detect one strand breakage/ chromosome) and has the advantage over alkaline elution techniques in that it is not influenced by effects on the conformation of the DNA coil. ${ }^{24}$ The DNA adduct, $8-O H d G$, was measured in lymphocyte DNA with high performance liquid chromatography (HPLC) coupled with electrochemical detection as previously described by Faux et al. ${ }^{25}$

\section{ANALYSES OF CHROMIUM CONCENTRATIONS IN WHOLE BLOOD, PLASMA, URINE, AND LYMPHOCYTES}

Total chromium concentrations were measured with an electrothermal atomic absorption spectrophotometer with Zeeman background correction (Varian Zeeman Spectra AA-300). Methods for measuring the chromium concentrations in blood, plasma, and lymphocytes were based on that described by Schermaier et $a l^{20}$ with a detection limit of $0.025 \mu \mathrm{g} / \mathrm{l}$. Measurement of urinary chromium concentrations was carried out by a technique described by Halls and Fell ${ }^{27}$ with a detection limit of $0.26 \mu \mathrm{g} / \mathrm{l}$ of biological sample. The creatinine concentrations in the urine samples were analysed based on the Jaffé reaction with a Pye Unicam SP-550 UV/VIS spectrophotometer. Seronorm 115 trace element urine control material (containing $9.4 \mathrm{mmol}$ creatinine/l) was used for quality control of measuring creatinine.

The sample size was small and we could not show that the data was normally distributed therefore, a non-parametric statistical

Table 2 Mean (SEM) chromium concentrations in body fluids and isolated lymphocytes

\begin{tabular}{lll}
\hline Biological matrix & Exposed & Control \\
\hline Whole blood $(\mu \mathrm{g} / \mathrm{l} \mathrm{n}=10)$ & $5.50(1 \cdot 20)^{\star \star}$ & $0.73(0.13)$ \\
Plasma $(\mu \mathrm{g} / \mathrm{l}, \mathrm{n}=10)$ & $2.8(0 \cdot 38)^{\star \star}$ & $0.65(0.12)$ \\
Urine $(\mu \mathrm{g} / \mathrm{n}=10)$ & $7 \cdot 1(1 \cdot 1)^{\star \star}$ & $0.55(0.08)$ \\
Urine $(\mu \mathrm{g} / \mathrm{g}$ creatinine, $\mathrm{n}=10)$ & $5.97(1 \cdot 1)^{\star \star}$ & $0.76(0.13)$ \\
Lymphocytes $\left(\mu \mathrm{g} / 10^{10}\right.$ cells, $\left.\mathrm{n}=9\right)$ & $1.01(0.08)^{\star}$ & $0.76(0.03)$ \\
\hline$\star \mathrm{P}<0.05 ; \star \star \mathrm{P}<0.01$. & &
\end{tabular}

Table 3 Mean (SEM)\% breaks in DNA strands and formation of 8-OHdG in isolated human lymphocytes in vivo

\begin{tabular}{lll}
\hline DNA alterations & Exposed $(n=9)$ & Control $(n=6)$ \\
\hline D-S DNAt & $59(7)^{\star}$ & $50(5)$ \\
8-OHdG/dG & $0.037(0.007)^{\star}$ & $0.041(0.006)$ \\
\hline
\end{tabular}

$\star \mathrm{P}>0.05$.

†Double stranded DNA remaining.

test (Mann-Whitney) and linear regression analysis were used for data analysis with a Minitab statistics package.

\section{Results}

ASSESSMENT OF INTERNAL CHROMIUM EXPOSURE

Chromium concentrations in whole blood, plasma, and urine specimens from subjects exposed to chromium were significantly higher $(P<0.01)$ than those of the controls (table 2). Chromium concentrations in isolated lymphocytes from exposed subjects were only marginally higher $(P<0.05)$ than the controls (table 2).

DETECTION OF DNA ALTERATIONS IN ISOLATED HUMAN LYMPHOCYTES

Breaks in DNA strand and 8-OHdG measured in isolated lymphocytes showed no significant difference between the exposed and control groups (table 3).

\section{RELATION BETWEEN CHROMIUM}

CONCENTRATIONS IN BODY FLUIDS AND IN ISOLATED LYMPHOCYTES IN EXPOSED WORKERS

Linear regression analysis for the data of the group exposed to chromium showed that no significant linear relation $(P>0.05)$ was found when the chromium concentration in lymphocytes was compared with the chromium concentration in whole blood, plasma, and urine. When these data were converted to a ratio of whole blood chromium concentration to plasma chromium concentration, there was a significant linear relation between the chromium concentration in lymphocytes and the ratio ( $r=0.69$; fig 1$)$. This ratio was previously suggested as a reliable index for the assessment of exposure to chromium(VI) ${ }^{28}$ The relation between chromium concentrations in urine and in

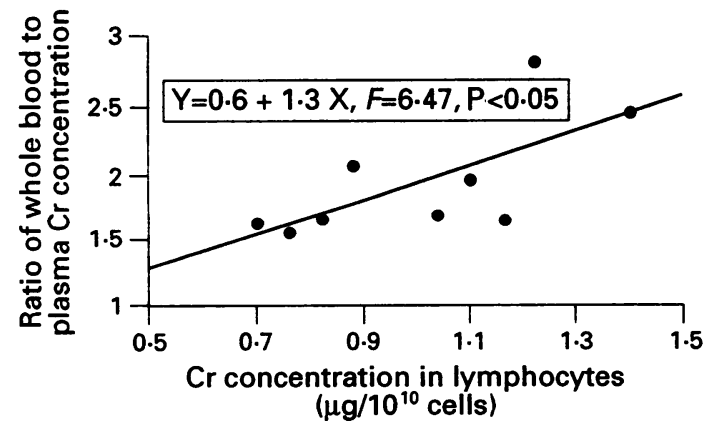

Figure 1 Relation between chromium concentration in lymphocytes and ratio of whole blood to plasma chromium concentration. The data used for this regression analysis were from the group exposed to chromium $(n=9)$. 
Figure 2 Relation between chromium concentrations in urine and whole blood from the group exposed to chromium $(n=9)$.

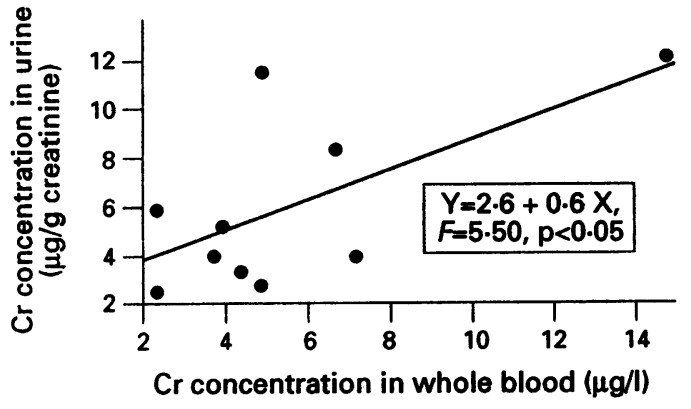

whole blood, plasma, and lymphocytes was also investigated with linear regression analysis. The relation was marginally significant $(\mathrm{P}<0.05)$ only between urine and whole blood $(r=0.64$; fig 2$)$.

\section{CONSIDERATION OF POSSIBLE CONFOUNDING VARIABLES ON DNA DAMAGE IN ISOLATED LYMPHOCYTES AND CHROMIUM CONCENTRATIONS IN SAMPLES FROM EXPOSED WORKERS}

Although there was no evidence of a difference in the extent of DNA damage, either in DNA strand breaks or the formation of 8-OHdG, between controls and the exposed group, there seemed to be an increased effect of smoking on both DNA strand breaks and 8-OHdG. The difference, however, was not significant. Chromium concentrations were also higher in the lymphocytes, whole blood, and urine of the exposed smokers although again, the difference was not significant (table 4). The increased DNA damage could reflect this extra chromium burden, or, it could reflect DNA damage caused by smoking itself. Due to the smaller numbers of smokers in the control group, no such comparison could be made for this group.

\section{Discussion}

The findings show that chromate production workers have a significantly higher chromium concentration in whole blood, plasma, and urine than do non-exposed workers (control group). Our finding of a mean (SEM) urinary chromium concentration of $7 \cdot 1 \quad(1 \cdot 1) \mu \mathrm{g} / 1$ $(5.97(1.1) \mu \mathrm{g} / \mathrm{g}$ creatinine) is broadly in accordance with the range of findings reported in other groups of workers exposed to chromium. In particular, a mean urinary chromium concentration has been reported as $31.5 \mu \mathrm{g} / 1$ (creatinine concentrations not

Table 4 Mean (SEM) chromium concentrations in biological matrices of smokers and non-smokers from the group exposed to chromium

\begin{tabular}{|c|c|c|}
\hline Biological matrix & $\begin{array}{l}\text { Smokers } \\
(n=6)\end{array}$ & $\begin{array}{l}\text { Non-smokers } \\
(n=4)\end{array}$ \\
\hline $\begin{array}{l}\text { Lymphocytes } \\
\left(\mu \mathrm{g} / 10^{10} \text { cells }\right)\end{array}$ & $1.14(0.09)^{\star}$ & $0.85(0.08)$ \\
\hline $\begin{array}{l}\text { Whole blood }(\mu \mathrm{g} / \mathrm{l}) \\
\text { Plasma }(\mu \mathrm{g} / 1) \\
\text { Urine }(\mu \mathrm{g} / \mathrm{g} \text { creatinine })\end{array}$ & $\begin{array}{l}5.87(1.80) \\
2.80(0.55) \\
6.26(1.80)\end{array}$ & $\begin{array}{l}4.95(1.20) \\
2 \cdot 80(0.55) \\
5.55(1.10)\end{array}$ \\
\hline
\end{tabular}

$P>0.05 .{ }^{\star} n=5$. reported) in a group of chromate production workers. ${ }^{16}$ In chromate pigment production workers, urinary chromium has been reported as $6-121 \mu \mathrm{g} / \mathrm{g}$ creatinine, $20-214 \mu \mathrm{g} / 1$ for blood, and $25-105 \mu \mathrm{g} / 1$ for serum. ${ }^{9}$ In stainless steel welders, urinary chromium concentration was 1.0 and $5-15 \mu \mathrm{g} / \mathrm{g}$ creatinine in two studies. ${ }^{1129}$ A group of chromium platers had an average urinary concentration of 9 $\mu \mathrm{g} / \mathrm{g}$ creatinine. ${ }^{30}$ Thus, it can be seen that in comparison with most of these reported studies, the chromium concentrations in our study are low (table 2). The low urinary concentrations are consistent with the low estimated airborne concentrations of chromium that the workforce are exposed to $\left(<0.01 \mathrm{mg} / \mathrm{m}^{3}\right)$. This reasoning is based on a presumed relation between airborne chromium exposure and urinary chromium concentration where it has been calculated that a urinary chromium concentration of $33 \mu \mathrm{g} / \mathrm{g}$ creatinine corresponds to an airborne exposure of 0.05 $\mathrm{mg} / \mathrm{m}^{3}{ }^{31}$ This is, of course, without the use of personal protection. In our study, respiratory protection was used in some locations.

Mean chromium concentrations in whole blood, plasma, and urine from the unexposed control group were $0.73 \mu \mathrm{g} / \mathrm{l}, 0.65 \mu \mathrm{g} / \mathrm{l}$, and $0.76 \mu \mathrm{g} / \mathrm{g}$ creatinine $(0.55 \mu \mathrm{g} / \mathrm{l})$ respectively (table 2), which are in good agreement with previous reported findings. ${ }^{91132}$ The Health and Safety Executive reported whole blood chromium concentrations at $<1.0 \mu \mathrm{g} / 1$ for apparently unexposed healthy people. ${ }^{33}$ Our findings indicate that the chromium concentrations in the body fluids of controls were all within the accepted normal range. The results of these chromium concentrations in the control group confirm two points. Firstly, that the techniques used for the analysis of chromium, in these biological matrices were feasible and secondly, that the actual concentrations measured, which were well within the published range of unexposed populations, strongly suggested that there was no uptake of chromium from occupational sources in our control population.

Chromium concentrations in isolated lymphocytes were modestly, but significantly $(P<0.05)$ increased $\quad(1.3$-fold; ratio $1 \cdot 14 / 0 \cdot 74)$ in the group exposed to chromium compared with the control group whereas increases in whole blood, plasma, and urine were increased $7 \cdot 5,4 \cdot 3$, and $7 \cdot 9$-fold respectively (all $\mathrm{P}<0.01$ ). This contrasts with Coogan et al who reported that lymphocytes accumulate chromium to a greater extent than red blood cells in vitro and in vivo. ${ }^{13}$ An animal study also showed that chromium was accumulated selectively in lymphocytes after intratracheal treatment with sodium dichromate at $0.44 \mathrm{mg} \mathrm{Cr} / \mathrm{kg}^{28}$ The present finding does not necessarily contradict the animal study, as the difference might be explained by the very low chromium exposures in the workplace in this study compared with the above two studies. In the workplace, the relatively smaller amount of chromium(VI) absorbed may also have been due to its reduction to chromium(III) in the plasma thus preventing 
entry into the lymphocytes. Lewalter et al have reported that absorbed chromium(VI) can penetrate erythrocytes, ${ }^{12}$ but this penetration is dependent on the chromium(VI) concentration absorbed, as human plasma is capable of spontaneous reduction of chromium(VI) to chromium(III) up to 200 $\mu \mathrm{g} / 1$. This may be due to reducing agents, such as ascorbic acid, in the plasma. ${ }^{12} \mathrm{~A}$ recent study reported that plasma reducing capabilities for chromium(VI) ranged from 25 to $33 \mu \mathrm{g} / \mathrm{l}$, however, these reducing capabilities did not correlate with plasma ascorbic acid concentration. ${ }^{34}$

There was no significant effect of chromium exposure on damage to DNA, measured as DNA strand breaks and formation of 8-OHdG, in the present study. This accords with the findings of an animal study in which a single intratracheal dose of sodium dichromate $(0.04 \mathrm{mg} \mathrm{Cr} / \mathrm{kg})$, approximately corresponding to an exposure level at the MEL of $0.05 \mathrm{mg} / \mathrm{m}^{3}$ over an $8 \mathrm{~h}$ working day, was not found to induce increased DNA strand breaks in rat lymphocytes compared with controls. ${ }^{20}$ This is also consistent with the results of chromium concentration in lymphocytes. Thus, these present findings further suggest that the current MEL may provide protection against DNA damage and that the measurement of chromium concentration in lymphocytes is relevant when these cells are used for assessing genotoxic effects induced by chromate.

Linear regression analysis for the group exposed to chromium showed that chromium concentration in urine was not correlated to the concentration in plasma and lymphocytes. There was only a weak association between urine and whole blood chromium concentrations (fig 2). Measurement of urine chromium concentration alone was not sufficient to evaluate the real internal exposure to chromium, ${ }^{29}$ especially when exposure contains different valency species of chromium. Minoia and Cavelleri have reported that a clear relation between exposure and urinary total chromium concentration after a shift exists in workers exposed to $\mathrm{Cr}(\mathrm{VI})$, and urinary concentration in workers exposed to high concentrations of chromic sulphate (Cr(III)) were lower. A linear relation was established when whole blood and plasma chromium concentrations were converted to a ratio and then compared with chromium concentration in the lymphocytes (fig 1). This agrees with previous findings that both lymphocytes and red blood cells can selectively accumulate chromium(VI), and the ratio of blood to plasma chromium may be a useful indicator of exposure to chromium(VI). ${ }^{12132835}$

Smoking as a possible cause of DNA damage was investigated in this study (table 4). Slightly increased chromium concentrations in lymphocytes, whole blood, and urine were found in cigarette smokers compared with non-smokers from the exposed group (table 4). These increased concentrations were not significantly higher when compared with those of non-smokers, which agrees with find- ings reported by Bukowski et al. ${ }^{36}$ In our study it should be noted that we have only classified subjects into smokers and non-smokers. Cigarette tobacco contains chromium from 0.24 to $6.3 \mathrm{mg} / \mathrm{kg}^{2}$. The smokers in this investigation were not heavy smokers; most smoked between 10 and 20 cigarettes/day. A small effect of smoking on DNA damage was found in the group exposed to chromium, measured as increases in DNA strand breaks and formation of $8-\mathrm{OHdG}$. Breaks in DNA strands induced by smoking and formation of 8-OHdG have previously been investigated. ${ }^{37-39}$ Clearly, these results make it vital that investigators should always consider the effect of smoking in any studies of chemically induced DNA damage.

According to our present findings, it would seem that the results that show no DNA damage to circulating peripheral lymphocytes, may give a certain measure of security to the chromate production workers under the present airborne exposure conditions (generally below $0.01 \mathrm{mg} \mathrm{Cr}(\mathrm{VI}) / \mathrm{m}^{3}$ ) and with whatever respiratory protection is customary. This is well below the United Kingdom MEL of $0.05 \mathrm{mg} \mathrm{Cr}(\mathrm{VI}) / \mathrm{m}^{3} .^{2}$ It may also indicate that the use of lymphocytes for biomonitoring of chromium exposure at such low air concentrations of chromium may be inappropriate. Thus, in the light of this pilot study and the implications discussed above, it is important that priority should be given to the study of populations with higher exposure to chromium, closer to the United Kingdom MEL than that of the present study.

We thank the workforce and management of British Chrome and Chemicals for their participation in the study and the medical staff for organising and collecting the biological sammedical staff for organising and collecting the biological sam-
ples. We would also like to thank $\mathrm{Dr} J \mathrm{~K}$ Chipman and
Professor $\mathrm{R}$ Colman (School of Biochemistry, University of Professor R Colman (School of Biochemistry, University of
Birmingham) for use of the high performance liquid chromatograph and fluorimeter respectively. The study was partly supported by Scott Moncrieff Fund, the Medical School of the University of Birmingham.

1 International Agency for Research on Cancer. Monographs on the evaluation of the carcinogenic risk of chemicals to humans. Vol. 49. Chromium, nickel and welding. Lyon: IARC 1990;49:49-256.

2 World Health Organisation Regional Office for Europe. Air quality guidelines for Europe. WHO Regional 1988:221-32. (WHO Regional Publ, European Series No. 23.)

3 Occupational Exposure Limits. London HMSO, 1993. (EH 40/93 Health and Safety Executive.)

4 Langård S. Biological and environmental aspects of chromium. Oxford: Elsevier 1982.

5 Norseth $T$. The carcinogenicity of chromium and its salts. $B r \mathcal{F}$ Ind Med 1986;43:649-51.

6 Mutti A, Pedroni C, Arfini G, Franchini I, Minoia C, Micoli G, Baldi C. Biological monitoring of occupational exposure to different chromium compounds at various valency states. International foumal of Analytical Chemistry 1984;17:35-41.

7 Suzuki Y, Homma K, Ninami $M$, Yoshikawa $H$. Distribution of chromium in rats exposed to hexavalent Distribution of chromium in rats exposed to hexavalent chromium and triva

8 Lindberg E, Vesterberg O. Monitoring exposure to chromic acid in chrome plating by measuring chromium in urine. Scand $\mathcal{F}$ Work Environ Health 1983;9:333-40.

9 McAughey J, Samuel AM, Baxter PJ, Smith NJ. Biological monitoring of occupational exposure in the chromate pigment production industry. Sci Total Environ 1988;71:317-22.

10 Cornelis R. Analytical procedure and clinical reference materials in monitoring human exposure to trace metals with special reference to $\mathrm{Cr}, \mathrm{Pb}$ and $\mathrm{Ti}$. Sci Total Environ 1988;71:269-83.

11 Bonde JP, Christensen JM. Chromium in biological sam- 
ple from low level exposed stainless steel and mild steel welders. Arch Environ Health 1991;46:225-9.

12 Lewalter J, Korallus V, Harzdorf C, Weidemann $H$ Chromium bond detection in isolated erythrocytes: a new principle of biological monitoring of exposure to hexavalent chromium. Int Arch Occup Environ Health hexavalent chroming

13 Coogan TP, Squibb KS, Motz J, Kinney PL, Costa M. Distribution of chromium within cells of the blood. Toxicol Appl Pharmacol 1991;108:157-66.

14 Perera FP, Hemminki K, Gryzbowska E, Motykiewicz G, Michalska J, Santella RM, et al. Molecular and genetic damage in humans from environmental pollution in Poland. Nature 1992;360:256-8.

15 Garner C. Epidemiology molecular potential. Nature 1992;360:207-8.

16 Perera F. The potential usefulness of biological markers in risk assessment. Environ Health Perspect 1987;76:141-5.

17 Tanigawa T, Araki S, Araki T, Minato N. A decrease in Leu-11a negative lymphocytes in relation to natural killer cell activity in chromate workers. $\mathrm{Br} \mathcal{F}$ Ind $\mathrm{Med}$ 1991;48:211-3.

18 Coogan TP, Motz J, Christie NT. Repair of X-ray induced DNA strand damage by isolated rat splenic lymphocytes. Mutat Res 1992;293:39-46.

19 Levy LS, Gao M, Binks SP. The role of DNA damage as a biomarker in risk assessment for carcinogens. Indoor Environment. March-April 1992; 125.

20 Gao M, Binks SP, Chipman JK, Levy LS, Braithwaite RA Brown SS. The in-vitro induction of DNA single strand breaks in human lymphocytes by chromium compounds. Hum Exp Toxicol 1992;11:77-82.

21 Faux SP, Gao M, Chipman JK, Levy LS. Production of 8 hydroxydeoxyguanosine in isolated DNA by chromium (VI) and chromium (V). Carcinogenesis 1992;13:1667-9.

22 Davies JM, Easton DF, Bidstrup PL. Mortality from respiratory cancer and other causes in United Kingdom chromate production workers. $B r f$ Ind Med 1991;48: 299-313.

23 Bimboim HC, Jevcak JJ. Fluorimetric method for rapid detection of DNA strand breaks in human white blood cells produced by low doses of radiation. Cancer Res 1981;41:1889-92.

24 Parodi S, Abelmoschi ML, Balbi C, De Angeli MT, Pala $\mathrm{M}$, Russo $\mathrm{P}$, et al. DNA damage in mouse and rat liver by caprolactam and benzoin evaluated

25 Faux SP, Francis JE, Smith AG, Chipman JK. Induction of 8-hydroxydeoxyguanosine in $\mathrm{A} h$-responsive mouse liver by iron and Aroclor 1254. Carcinogenesis 1992;13:247-50.

26 Schermaier AJ, O'Connor LH, Pearson KH. Semi-automated determination of chromium in whole blood and serum by Zeeman electrothermal atomic absorption spectrophotometry Clin Chim Acta 1985;152:123-34.

27 Halls DJ, Fell GS. The problem of background correction in the determination of chromium in urine by atomic spectrometry with electrothermal atomisation. Fournal of spectrometry with electrothermal atomis.

28 Gao M, Levy LS, Braithwaite RA, Brown SS. Monitoring of total chromium in rat fluids and lymphocytes following intratracheal administration of soluble trivalent or hexavalent chromium compounds. Hum Exp Toxicol 1993; 12:377-82.

29 Franchini R, Mutti A, Cavatorta E, Pedroni C, Borghetti A. Chromium. In: Alessio L, Berlin A, Boni M, Roi R, eds. Biological indicators for the assessment of human exposure 1984:33-51. (Establishment EUR 8903 EN.)

30 Verschoor MA, Bragt PC, Herber RFM, Zielhuis RL, Zwennis WCM. Renal function of chrome-plating workers and welders. Int Arch Occup Environ Health 1988; 60:67-70.

31 Tola S, Kilpiö J, Virtamo M, Haapa K. Urinary chromium as an indicator of the exposure of welders to chromium Scand $\mathcal{F}$ Work Environ Health 1977;3:192-202.

32 Morris BW, Griffith H, Hardisty CA, Kemp GJ. Increased concentration of chromium in plasma, urine and red blood cells in a group of stainless steel welders. fournal of Analytical Spectroscopy 1989;10:1-3.

33 Health and Safety Executive. Laboratory methods for biological monitoring. 4th ed. London: HMSO, 1989.

34 Capellmann M, Bolt HM. Chromium(VI) reducing capacity of ascorbic acid and of human plasma in vitro. Arch Toxicol 1992;66:45-50.

35 Minoia C, Cavalleri A. Chromium in urine, serum, and red blood cells in the biological monitoring of workers exposed to different chromium valency states. Sci Total Environ 1988;71:323-7.

36 Bukowski JA, Goldstein MD, Korn LR, Johnson BB. Biological markers in chromium exposure assessment confounding variables. Arch Environ Health 1991;46: 230-6.

37 Schwalb G, Anderson R. Increased frequency of oxidantmediated DNA strand breaks in mononuclear leucocytes exposed to activated neutrophils from cigarette smokers. Mutat Res 1989;225:95-9.

38 Kiyosawa $\mathrm{H}$, Suko $M$, Okudaira $\mathrm{H}$, Murata $\mathrm{K}$, Miyamoto $\mathrm{T}$, Chung M-H, et al. Cigarette smoking induces formation of 8-hydroxydeoxyguanosine, one of the oxidative tion of 8-hydroxydeoxyguanosine, one of the oxidative Res Commun 1990;11:23-7.

39 Chung FL, Xu Y. Increased 8-oxydeoxyguanosine levels in lung DNA of $A / J$ mice and F344 rats treated with the obacco-specific nitrosamine 4-(methylnitrosamine)-1 1(3-pyridyl)-1-butanone. Carcinogenesis 1992;13:1269-72. 